\title{
HUBUNGAN PEMAHAMAN TEORI EVOLUSI DAN TINGKAT RELIGIOSITAS DENGAN PENERIMAAN TEORI EVOLUSI \\ (Studi Pada Mahasiswa Pendidikan Biologi Universitas Negeri Jakarta) \\ CORRELATION OF EVOLUTIONARY THEORY UNDERSTANDING AND RELIGI- OSITY WITH EVOLUTIONARY THEORY ACCEPTANCE (Study to Biology Education Students of State University of Jakarta)
}

\author{
Desty Bulandari, Rusdi, Agung Sedayu \\ Universitas Negeri Jakarta \\ Jalan Raya Rawamangun Muka, Jakarta Timur 13220 \\ E-mail: destybulandd@gmail.com,rusdi@unj.ac.id, asedayu@unj.ac.id
}

Naskah diterima tanggal: 25-02-2019 disetujui tanggal: 22-10-2019

\begin{abstract}
Many people, including academics do not consider the theory of evolution as a valid scientific theory so that the rejection of the theory of evolution emerges. The preference of Biology teacher for teaching evolution in the classroom is determined by the acceptance of such controversial topic. Indonesia as a Muslim-majority nation has implemented four core competencies (religious, social, knowledge, and skill) to be achieved by students in each lesson. Biology Education students who understand the theory of evolution in the future is expected to not avoid teaching evolution by excuse that evolution contradicts religious tenet. This study aimed to determine the correlation of evolutionary theory understanding and religiosity with evolutionary theory acceptance in Biology Education students who believe in Islam. Research conducted at State University of Jakarta in September-December 2018. The method used was a correlational survey. Data were analyzed using multiple correlation coefficient significance test. The results showed that there was a significant positive correlation of evolutionary theory understanding and religiosity with evolutionary theory acceptance. Therefore, evolution course taken by Biology Education students was needed to aware of clear understanding about evolutionary theory. In addition, educators need wide insight to not consider religiosity and evolutionary acceptance were in opposite.
\end{abstract}

Keywords: biology education, religiosity, theory of evolution

\begin{abstract}
Abstrak: Banyak orang termasuk akademisi tidak menganggap teori evolusi sebagai teori ilmiah yang valid sehingga timbul penolakan terhadap teori evolusi. Adapun kecenderungan guru Biologi untuk mengajarkan materi evolusi dalam kelas ditentukan oleh penerimaan terhadap materi kontroversial tersebut. Indonesia sebagai negara mayoritas Muslim menerapkan empat kompetensi inti (religius, sosial, pengetahuan, dan keterampilan) untuk dicapai siswa dalam tiap materi pembelajaran. Mahasiswa Pendidikan Biologi yang memahami teori evolusi di kemudian hari diharapkan tidak menghindar dalam mengajarkan evolusi dengan dalih evolusi kontradiksi terhadap ajaran agama. Penelitian ini bertujuan untuk mengetahui hubungan antara pemahaman teori evolusi dan tingkat religiositas dengan penerimaan teori evolusi pada mahasiswa Pendidikan Biologi yang beragama Islam. Metode yang digunakan adalah survei korelasional. Penelitian dilaksanakan di Universitas Negeri Jakarta pada September-Desember 2018. Data dianalisis dengan uji signifikansi koefisien korelasi berganda. Hasil penelitian menunjukkan bahwa terdapat hubungan positif signifikan antara pemahaman teori evolusi dan tingkat religiositas dengan penerimaan teori evolusi. Oleh karena itu, pembelajaran evolusi terhadap mahasiswa Pendidikan Biologi perlu
\end{abstract}


memperhatikan pemahaman mendalam tentang teori evolusi. Di samping itu, pengajar perlu berwawasan luas agar tidak menganggap religiositas dan penerimaan teori evolusi bertolak belakang.

Kata kunci: pendidikan biologi, religiositas, teori evolusi

\section{PENDAHULUAN}

Tujuan pendidikan sains di abad ke-21 melibatkan kemampuan menyelesaikan masalah, menentukan keputusan berdasarkan bukti ilmiah, dan mengevaluasi informasi secara logis (Glaze, 2018). Tujuan tersebut menjadi tantangan untuk dicapai pada materi evolusi, karena materi tersebut dianggap memiliki karakteristik khusus, yakni kontradiksi dengan pandangan agama.

Futuyma (2013) mendefinisikan evolusi sebagai hipotesis yang didasari oleh observasi ilmiah yaitu bahwa karakteristik kelompok antargenerasi berubah. Ridley (2004) menyatakan bahwa beberapa tokoh sebelum Darwin telah menggagas perubahan spesies sepanjang waktu menjadi spesies lain, yang paling terkenal adalah Lammarck. Akan tetapi, kebanyakan ahli Biologi di pertengahan abad 19 meyakini bahwa wujud spesies tetap. Misalnya, Darwin menentang kepercayaan tradisional dengan gagasan bumi berusia lebih dari bilangan ribuan tahun dan spesies yang ditemukan saat ini berkembang dari nenek moyang yang sama.

Dalam pendidikan di Indonesia, evolusi klasik yang membandingkan gagasan Lammarck dan Darwin termasuk materi pokok yang diajarkan di kelas IX. Sementara itu, evolusi modern yang dilandasi aspek molekuler tergolong kompetensi dasar pada kurikulum Biologi kelas XII. Meski begitu, teori evolusi yang mencakup gagasan Darwin mengenai keturunan dengan modifikasi dan seleksi alam tak henti menuai penolakan sejak dipublikasikan pada 1859.

Walaupun tergolong esensial dalam perkembangan biologi, validitas teori evolusi modern yang sejak abad 20 telah diperkuat oleh konsep hereditas Mendel masih dipandang kontroversial di tengah masyarakat (Miller, Scott, \& Okamoto,
2006). Bahkan, pemerintah Turki memutuskan untuk melarang pembelajaran evolusi di SMA mulai 2017. Pelarangan serupa juga pernah diberlakukan di Kansas pada 1990-2001 (Evans, 2017).

Hasil studi sosiologis sejak 1996 hingga 2003 menunjukkan bahwa hanya sekitar $16 \%$ orang Indonesia yang setuju bahwa teori evolusi Darwin mungkin atau hampir pasti benar (Hameed, 2008). Alters \& Nelson (2002) menyatakan bahwa penolakan terhadap evolusi di antaranya disebabkan oleh fakta tidak ilmiah yang diajarkan oleh orang tua, publik, dan kadang guru di sekolah atau dipelajari dari fiksi. Selain itu, diduga akibat penyampaian ajaran religius dalam pelajaran sains.

Di Indonesia, pelajaran IPA kelas IX memuat materi adaptasi dan seleksi alam dalam kompetensi dasar 3.3: Menerapkan konsep pewarisan sifat dalam pemuliaan dan kelangsungan makhluk hidup. Adapun kurikulum Biologi kelas XII turut mengandung konsep evolusi berdasarkan aspek molekuler dalam kompetensi dasar 3.9: Menjelaskan teori, prinsip, dan mekanisme evolusi serta pandangan terkini para ahli terkait spesiasi serta 4.9: Menyajikan karya ilmiah terhadap gagasan baru tentang kemungkinan-kemungkinan pandangan evolusi berdasarkan pemahaman yang dimilikinya (Rachmatullah, Nehm, Roshayanti, \& Ha, 2018).

Sebagai calon figur yang memiliki independensi dalam menyampaikan informasi, mahasiswa Pendidikan Biologi di kemudian hari diharapkan mampu membekali siswa memahami konsep evolusi. Hal ini disebabkan materi evolusi termasuk kompetensi dalam Ujian Nasional SMP dan SMA serta SBMPTN. Adapun kemampuan seorang guru dalam menjelaskan konsep evolusi 
yang benar didahului oleh penerimaan terhadap teori evolusi (Trani, 2004). Menurut Winkel (2014), penerimaan adalah pilihan kecenderungan dalam menyikapi suatu objek berdasarkan penilaian kebergunaan atau keberhargaan objek tersebut bagi dirinya.

Allmon (2011) menyatakan bahwa penyebab seseorang tidak menerima evolusi meliputi (1) rendahnya pemahaman bukti empiris dan konten teori evolusi modern, (2) rendahnya pemahaman filsafat ilmu, (3) agama diantaranya Yahudi, Kristen, Islam, dan Hindu yang kebenaran literal dari kitab sucinya dipertanyakan oleh konsep evolusi, (4) berbagai faktor psikologis, serta (5) faktor politis dan sosial. Rutledge \& Warden (2000) menyatakan bahwa pemahaman berkontribusi terhadap pengambilan keputusan untuk menerima atau menolak sesuatu. Pada guru Biologi, pemahaman evolusi menentukan penerimaan evolusi dan kecenderungan untuk mengajarkan materi evolusi dalam kelas (Tekkaya, Akyol, \& Sungur, 2012).

Menurut Heddy \& Nadelson (2012), tingkat religiositas diduga turut menentukan penerimaan evolusi, terkait spekulasi yang menganggapnya bertentangan dengan agama dalam hal penciptaan. Kwon (2003) menjelaskan bahwa religiositas berarti tingkatan di mana seseorang menerapkan komitmen terhadap agama pada tiap situasi. Terdapat banyak penelitian mengenai religiositas dan penerimaan teori evolusi di daerah dengan mayoritas penduduk beragama Kristen (Moore, Cotner, \& Bates, 2009; Trani, 2004; Wiles, 2014). Namun, masih sedikit yang dilakukan di wilayah mayoritas Muslim. Oleh karena itu, diperlukan penelitian mengenai hubungan antara pemahaman teori evolusi dan tingkat religiositas dengan penerimaan teori evolusi pada mahasiswa Pendidikan Biologi Muslim di Universitas Negeri Jakarta.

El-Menouar (2014) menyatakan bahwa tingkat religiositas pada Muslim meliputi lima dimensi, yaitu religiositas dasar, kewajiban utama, pengalaman, pengetahuan, dan ortopraksis. Sementara itu, guru Biologi di Indonesia yang termasuk negara mayoritas Muslim diharapkan memfasilitasi siswa untuk mempertimbangkan bagaimana gagasan evolusi berkaitan dengan perspektif religius dan spiritual sebagai implementasi Kompetensi Inti I dalam Kurikulum 2013 (Rachmatullah, Nehm, Roshayanti, \& Ha, 2018). Oleh karena itu, hipotesis pada penelitian ini adalah terdapat hubungan signifikan antara: (1) pemahaman dengan penerimaan teori evolusi, (2) tingkat religiositas dengan penerimaan teori evolusi, serta (3) pemahaman teori evolusi dan tingkat religiositas dengan penerimaan teori evolusi pada mahasiswa Pendidikan Biologi.

\section{METODE}

Penelitian ini dilaksanakan di Universitas Negeri Jakarta pada semester ganjil tahun ajaran 2018/ 2019 yaitu pada September sampai Desember 2018. Penelitian ini termasuk jenis kuantitatif dengan metode korelasional. Populasi dalam penelitian ini meliputi seluruh mahasiswa Pendidikan Biologi yang masih aktif kuliah di Universitas Negeri Jakarta yang telah menyelesaikan mata kuliah Evolusi dan beragama Islam. Pertama, dipilih 72 mahasiswa yang berada pada tahun ke-4 dengan purposive sampling. Dari 64 responden yang mengisi instrumen penelitian, ditentukan 60 sampel dengan simple random sampling.

Pengumpulan data menggunakan instrumen dengan indikator yang dapat dilihat pada Tabel 1. Instrumen penerimaan teori evolusi dimodifikasi dari instrumen Measurement of Acceptance of the Theory of Evolution (MATE) yang dikembangkan oleh Rutledge \& Warden (2000). Sementara itu, instrumen pemahaman teori evolusi berupa pilihan ganda yang dimodifikasi dari instrumen Rutledge \& Warden (2000) serta Moore, Cotner, \& Bates (2009). Adapun instrumen tingkat religiositas dimodifikasi 
dari instrumen yang dikembangkan oleh ElMenouar (2014). Data dianalisis melalui uji signifikansi model regresi dan koefisien korelasi berganda pada $\alpha=0,05$. Uji prasyarat analisis menunjukkan bahwa data berdistribusi normal.

Tabel 1 Indikator instrumen penelitian

Instrumen 1. Penerimaan Teori Evolusi

1. Proses Evolusi

Menyebutkan bahwa makhluk hidup mengalami evolusi dan menyetujui buktibukti evolusi

2. Keilmiahan Teori Evolusi Menggolongkan teori evolusi sebagai teori ilmiah dan menyebutkan teori evolusi sebagai teori yang valid

3. Evolusi Makhluk Hidup Membedakan bentuk organisme saat ini dan di masa lampau Instrumen 2. Pemahaman Teori Evolusi

1. Menggolongkan bukti ilmiah teori evolusi (homologi, fosil, variabilitas genetik)

2. Menjelaskan bagaimana variabilitas genetik dan lingkungan memengaruhi proses evolusi (spesiasi, keberhasilan reproduktif, evolusi konvergen)

3. Menjelaskan prinsip seleksi alam (biogeografi, proses kepunahan) Instrumen 3. Tingkat Religiositas

1. Religiositas dasar Meyakini Allah dan menunaikan ibadah

2. Kewajiban utama Memenuhi rukun iman

3. Pengalaman Keterlibatan Allah dalam keseharian

4. Pengetahuan Memikirkan dan memelajari topik agama

5. Ortropraksis Disiplin mematuhi norma agama

\section{HASIL DAN PEMBAHASAN}

Pemahaman teori evolusi pada mahasiswa Pendidikan Biologi tergolong rendah dengan nilai rata-rata $39.63(S D=14.3)$. Skor paling rendah didapati pada butir pertanyaan mengenai bukti evolusi berupa homologi dan bagian teori seleksi alam. Hasil ini sejalan dengan pernyataan Alters \& Nelson (2002), Putri, Rahman \& Priyandoko
(2017), serta Tavares \& Bobrowski (2018) bahwa pemahaman evolusi tidak hanya pada masyarakat melainkan juga mahasiswa ditemukan rendah oleh kebanyakan peneliti dan pendidik. Mata kuliah evolusi pada umumnya tersedia di semester enam (Rachmatullah, Nehm, Roshayanti, \& Ha, 2018). Meski demikian, mata kuliah yang diperoleh sejak semester awal sudah mengandung konten evolusi. Misalnya, bukti evolusi yang berkaitan dengan ilmu biokimia, perkembangan hewan, dan genetika serta konsep seleksi alam yang erat kaitannya dengan diversitas hewan dan tumbuhan. Menurut Anderson et al. (2001), pemahaman adalah kemampuan menghubungkan pengetahuan baru dengan pengetahuan sebelumnya. Oleh karena itu, pemahaman teori evolusi yang ditemukan rendah pada mahasiswa Pendidikan Biologi dapat diakibatkan oleh rendahnya kemampuan mengintegrasikan materi evolusi dengan disiplin Biologi yang telah diperoleh sebelumnya.

Tingkat religiositas mahasiswa Pendidikan Biologi yang beragama Islam termasuk tinggi dengan nilai rata-rata $85.50(S D=6.2)$. Artinya, sampel penelitian termasuk kelompok Muslim yang religius. Religiositas mahasiswa Muslim Pendidikan Biologi dapat dilihat dari budaya Muslim yang digagas organisasi Islam di Universitas Negeri Jakarta, antara lain seruan "Shalat Awal Waktu" dan "Tilawah Ba'da Shalat". Sementara itu, Badan Eksekutif Mahasiswa dan Kelompok Studi rutin mengagendakan kajian yang tidak hanya mengenai ilmu pengetahuan melainkan juga kaitannya dengan agama. ElMenouar (2014) menyatakan bahwa kebiasaan sosial berupa aktivitas agamais termasuk salah satu pendekatan untuk mengukur religiositas Muslim.

Nilai rata-rata penerimaan teori evolusi termasuk sedang yaitu sebesar 66.05 (SD=9.7). Mayoritas mahasiswa menyatakan persetujuan terhadap butir pernyataan mengenai ambiguitas data yang membuktikan terjadinya evolusi, 
adanya keraguan komunitas ilmiah terhadap evolusi, dan invaliditas teori evolusi secara ilmiah. Hasil ini sejalan dengan penelitian Rachmatullah, Nehm, Roshayanti, \& Ha (2018) yang menunjukkan bahwa penerimaan teori evolusi pada mahasiswa Pendidikan Biologi tergolong sedang. Meski menunjukkan penerimaan teori evolusi yang sedang, hasil tersebut lebih tinggi daripada penerimaan teori evolusi pada masyarakat umum yang didapati rendah oleh Hameed (2008). Hal ini dapat disebabkan adanya mata kuliah terkait evolusi yang ditempuh mahasiswa Pendidikan Biologi selama studi. Coleman, Stears, \& Dempster (2015) menyatakan bahwa penerimaan evolusi pada mahasiswa dapat meningkat berkenaan dengan pembelajaran dari dosen yang mendukung evolusi sebagai fakta ilmiah.

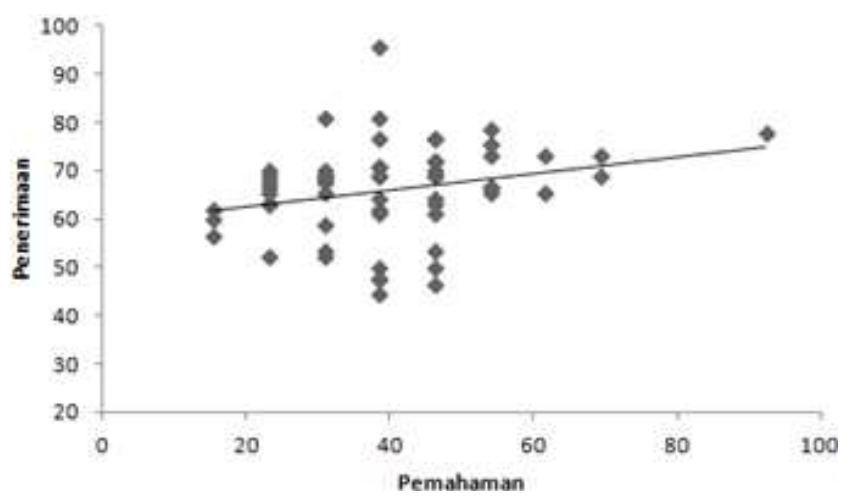

Gambar 1 Hubungan pemahaman $\left(\mathrm{X}_{1}\right)$ dengan penerimaan teori evolusi $(\mathrm{Y})$

Hasil pengujian model regresi sederhana menunjukkan bahwa model regresi signifikan pada persamaan $\hat{Y}=59.113+1.175 X_{1}(p=0.046)$. Grafik di atas menggambarkan persamaan regresi di mana pada konstanta 59.113, setiap kenaikan satu satuan nilai pemahaman teori evolusi menyebabkan kenaikan penerimaan teori evolusi pada mahasiswa Pendidikan Biologi sebesar 1.175. Adapun hasil pengujian linearitas menunjukkan bahwa model regresi linear.
Sementara itu, nilai koefisien korelasi $\left(r_{x 1 y}\right)$ yang diperoleh sebesar 0.259 , berarti terdapat hubungan positif signifikan yang lemah antara kedua variabel $(p=0.046)$ antara kedua variabel dengan nilai kontribusi $6.7 \%$.

Analisis korelasi antara pemahaman dengan penerimaan teori evolusi menunjukkan hubungan positif signifikan yang sejalan dengan hasil penelitian Rutledge \& Warden (2000) serta Trani (2004). Hal ini berarti mahasiswa yang memiliki pemahaman teori evolusi tinggi menunjukkan penerimaan teori evolusi yang juga tinggi. Menurut Rachmatullah, Nehm, Roshayanti, \& Ha (2018), pemahaman teori evolusi termasuk faktor penentu pola penalaran dan tingkat penerimaan terhadap teori evolusi pada mahasiswa Pendidikan Biologi di Indonesia. Meski begitu, koefisien korelasi yang diperoleh ( $r=$ 0.259) menunjukkan hubungan yang lemah. Menurut Moore, Notz, \& Flinger (2013), koefisien korelasi sangat dipengaruhi oleh deviasi dari rata-rata. Banyaknya nilai individu yang menyimpang dari keseluruhan pola hubungan berdasarkan model regresi (garis ideal) menjadi alasan ukuran kekuatan hubungan didapati rendah. Selain itu, sudut landai pada garis ideal model regresi (Gambar 1) merepresentasikan hubungan linear positif yang lemah.

Glaze (2018) menyatakan bahwa syarat penting akan penerimaan terhadap topik kontroversial seperti evolusi ialah literasi sains yang baik. Literasi sains yang dimaksud melibatkan tidak hanya kemampuan kognitif terhadap teori evolusi melainkan juga pemahaman filsafat ilmu. Dengan kata lain, kontribusi pemahaman teori evolusi terhadap penerimaan teori evolusi dapat menjadi kuat jika diiringi pemahaman mengenai metodologi dalam penyusunan teori ilmiah. Dengan begitu, seseorang yang memahami teori evolusi akan menerima teori evolusi dan tidak menganggapnya sebatas asumsi. 


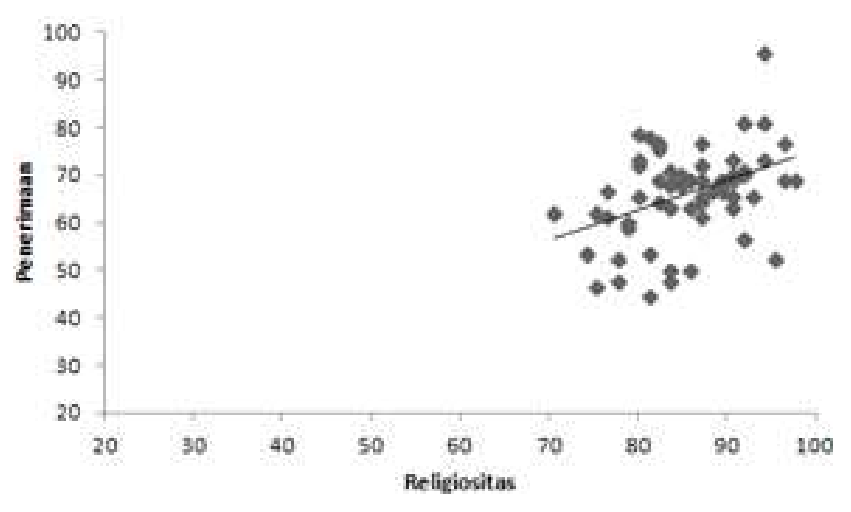

Gambar 2 Hubungan religiositas $\left(X_{2}\right)$ dengan penerimaan teori evolusi $(\mathrm{Y})$

Model regresi sederhana hasil pengujian berupa persamaan $\hat{Y}=13.267+0.617 \mathrm{X}_{2}$ tergolong signifikan $(p=0.002)$. Grafik di atas menggambarkan bahwa pada konstanta 13.267, setiap kenaikan nilai tingkat religiositas turut meningkatkan nilai penerimaan teori evolusi sebesar 0.617. Adapun model regresi tergolong linear $(p=0.060)$. Sementara itu, uji koefisien korelasi menunjukkan hubungan positif signifikan yang lemah $\left(r_{x 2 y}=0.397\right)$ antara kedua variabel $(p=0.002)$ dengan nilai kontribusi $15.8 \%$.

Analisis korelasi antara tingkat religiositas dengan penerimaan teori evolusi menunjukkan hubungan positif signifikan $(r=0.397)$ yang lemah. Goodwin \& Leech (2006) menyatakan bahwa salah satu faktor yang memengaruhi besaran koefisien korelasi didapati rendah ialah banyaknya jumlah individu dengan nilai menyimpang garis ideal model regresi. Sementara itu, sudut landai pada garis ideal model regresi merepresentasikan hubungan yang lemah (Gambar 2). Berdasarkan hasil pengujian hipotesis, dapat diinterpretasikan bahwa arah hubungan tingkat religiositas dengan penerimaan teori evolusi tergolong positif. Namun, hal ini tidak sesuai dengan penelitian pada populasi mayoritas Kristen yang umumnya menunjukkan adanya hubungan negatif (Trani, 2004; Heddy \& Nadelson, 2012). Hameed (2008) turut menyatakan bahwa Muslim umumnya menolak teori evolusi meski belum marak perdebatan mengenai kaitannya dengan religiositas. Hal tersebut tak terkecuali di Indonesia yang merupakan negara mayoritas Muslim terbesar di dunia.

Gagasan penolakan terhadap teori evolusi di kalangan Muslim berfokus pada ancaman materialisme dan ateisme (Hameed, 2008). Teori evolusi yang kerap diasosiasikan dengan ateisme menyebabkan anggapan Muslim bahwa menerima teori evolusi sama dengan menentang agama. Muslim menolak teori evolusi diduga akibat mengadaptasi argumen masyarakat Barat terutama Amerika dengan tingkat religiositas Kristen yang tergolong tinggi tanpa menelaah kaitan evolusi dengan ajaran Islam lebih lanjut (Dajani, 2012). Meski begitu, Sutantoputri \& Watt (2012) menyatakan bahwa mahasiswa Indonesia dengan tingkat religiositas tinggi lebih cenderung memiliki motivasi tinggi untuk mencapai tujuan pembelajaran. Oleh karena itu, tingkat religiositas tidak secara universal menjadi penghalang seseorang untuk menerima teori evolusi. Konteks kultural di suatu lingkungan perlu diperhatikan terkait hubungan antara tingkat religiositas dengan penerimaan teori evolusi.

Clément (2015) menyatakan bahwa penolakan terhadap evolusi lebih berkaitan dengan identitas sosiokultural seperti aspek politis, historis, dan tingkat ekonomi daripada tingkat religiositas terkait agama tertentu. Menurut Allmon (2011), penolakan atau penerimaan suatu gagasan tidak hanya tergantung pada karakteristik empiris, filosofis, atau psikologis tetapi juga figur yang mendukung atau menentangnya. Oleh karena itu, aspek politis yang meliputi persetujuan terhadap pandangan figur yang dianggap menguasai suatu ilmu, misalnya ilmuwan terkemuka atau dosen, dapat menjadi faktor penentu seseorang menerima evolusi. Selain itu, populasi yang umumnya berkecukupan secara ekonomi dapat memiliki kesempatan lebih luas untuk memperoleh pendidikan formal maupun informal 
sehingga penerimaan terhadap teori evolusi tidak terhambat (Heddy \& Nadelson, 2012). Dalam kultur yang didasari agama, pandangan guru tentang hakikat ilmu pengetahuan dan peruntukannya berkaitan dengan interpretasi dari prinsip religius (Mansour, 2010). Oleh sebab itu, mahasiswa Pendidikan Biologi yang memiliki religiositas Islam tinggi dapat menerima teori evolusi dengan tetap meyakini kehendak Allah terlibat di dalamnya. Hal ini sejalan dengan hasil penelitian Evehart \& Hameed (2013) yang menunjukkan bahwa seseorang dapat menerima evolusi dan juga meyakini Allah.

Hasil pengujian model regresi linear ganda menunjukkan bahwa model regresi signifikan pada persamaan $\hat{\mathrm{Y}}=7.758+0.166 \mathrm{X}_{1}+0.605 \mathrm{X}_{2}(p$ $=0.001)$. Diagram di atas menggambarkan persamaan regresi di mana pada konstanta 7.758, setiap kenaikan satu satuan nilai $X_{1}$ menyebabkan kenaikan $Y$ sebesar 0.166 dan setiap kenaikan satu satuan nilai $X_{2}$ menyebabkan kenaikan Y sebesar 0.605. Nilai koefisien korelasi ganda $\left(r_{x 1 \times 2 y}\right)$ yang diperoleh sebesar 0.467 , berarti terdapat hubungan positif yang sedang antara $X_{1}$ dan $X_{2}$ dengan $Y(p=$ $0.001)$. Adapun nilai kontribusi yang diperoleh yakni $21.8 \%$.

Pemahaman teori evolusi dan tingkat religiositas secara bersama-sama berkontribusi terhadap penerimaan teori evolusi sebesar $22 \%$ ( $r=0.467$ ) pada mahasiswa Pendidikan Biologi. Sementara itu, 78\% merupakan kontribusi aspek lain. Kontribusi tersebut diperoleh dari ukuran antara variabel acak $Y$ dan prediksinya dari model regresi (Asuero, Sayago, \& Gonzalez, 2006). Analisis korelasi ganda menunjukkan bahwa pemahaman teori evolusi dan tingkat religiositas dapat menjadi variabel yang secara sinergis menentukan penerimaan teori evolusi. Integrasi yang mendukung pemahaman teori evolusi pada mahasiswa Pendidikan Biologi melalui mata kuliah Biologi Umum, Filsafat Ilmu, hingga Evolusi dapat menyebabkan tingkat religiositas yang tinggi tidak menjadi penghalang terhadap penerimaan teori evolusi. Wiles (2014) menyatakan bahwa mahasiswa yang memiliki penerimaan teori evolusi lebih tinggi seringkali lebih berpikiran terbuka mengenai interpretasi religius.

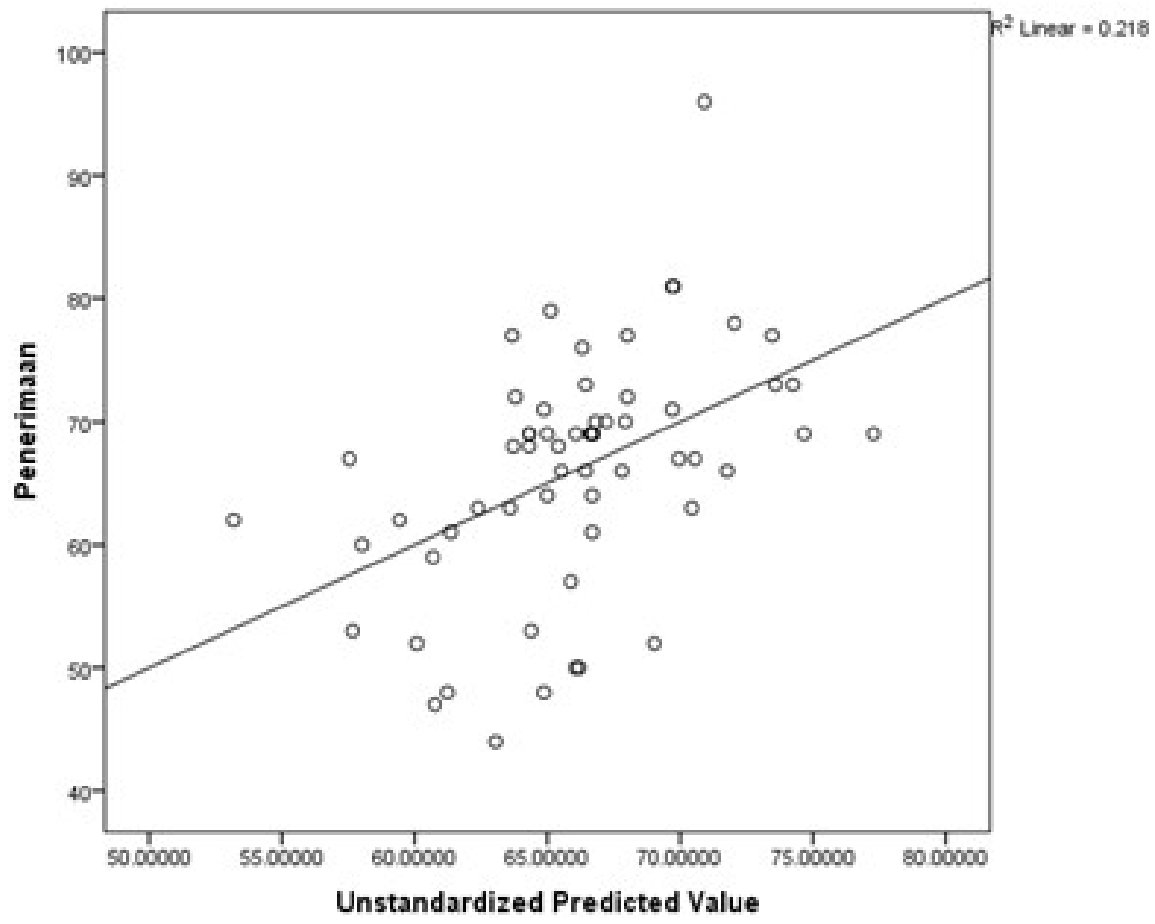

Gambar 3 Hubungan pemahaman teori evolusi $\left(X_{1}\right)$ dan tingkat religiositas $\left(X_{2}\right)$ dengan penerimaan teori evolusi $(Y)$ 
Mahasiswa Pendidikan Biologi di masa mendatang diharapkan dapat menjadi guru Biologi yang secara profesional bertanggung jawab terhadap instruksi dalam pembelajaran evolusi di kelas (Rutledge \& Warden, 2000). Adapun kurikulum terbaru yang diimplementasikan di sekolah yakni Kurikulum 2013 mengandung empat kompetensi inti (KI) dalam pembelajaran, meliputi: (1) religius, (2) sosial, (3) pengetahuan, dan (4) keterampilan (Rachmatullah, Nehm, Roshayanti, \& Ha, 2018). Oleh karena itu, guru dituntut untuk membimbing siswa dalam membandingkan relevansi teori evolusi dengan pandangan berbagai tokoh dari sisi keilmuan maupun agama. Dengan demikian, kemampuan untuk menentukan metode dalam menanggapi argumen terkait evolusi di kelas diperlukan bagi mahasiswa Pendidikan Biologi (Mansour, 2010).

Penelitian ini menunjukkan hasil yang tidak umum ditemukan pada komunitas religius (Trani, 2004; Hameed, 2008; Moore \& Cotner, 2009). Hal ini dapat disebabkan oleh karakter kultural mahasiswa Pendidikan Biologi Universitas Negeri Jakarta (UNJ) sebagai kalangan akademisi religius serta telah dibekali pembinaan kependidikan yang menuntut integrasi kompetensi religius dan pengetahuan dalam pengajaran. Oleh karena itu, mahasiswa Pendidikan Biologi UNJ dapat menerima teori evolusi tanpa memisahkan antara ilmu dan agama. Apabila penelitian serupa dilakukan pada populasi lain di Indonesia dengan karakter sosiokultural bervariasi bisa jadi tidak menunjukkan hasil yang seragam.

\section{SIMPULAN DAN SARAN}

\section{Simpulan}

Mahasiswa Pendidikan Biologi Universitas Negeri Jakarta (UNJ) secara umum memiliki pemahaman teori evolusi yang tergolong rendah. Hal ini berhubungan dengan fakta bahwa penerimaan teori evolusi para mahasiswa didapati tidak tinggi. Sementara itu, mahasiswa Pendidikan
Biologi yang beragama Islam ditemukan memiliki tingkat religiositas tinggi dan hal tersebut tidak menghambat penerimaan teori evolusi.

Analisis korelasi pemahaman teori evolusi maupun tingkat religiositas menunjukkan hubungan positif dengan penerimaan teori evolusi. Akan tetapi, hal ini tidak umum ditemukan pada komunitas religius. Karakter kultural mahasiswa Muslim Pendidikan Biologi UNJ sebagai kalangan akademisi religius serta telah dibekali pembinaan untuk mengintegrasikan kompetensi religius dan pengetahuan dalam pengajaran dapat menyebabkan pemahaman teori evolusi dan tingkat religiositas secara sinergis berkontribusi terhadap penerimaan teori evolusi.

\section{Saran}

Pembelajaran evolusi terhadap mahasiswa Pendidikan Biologi perlu memperhatikan pemahaman mendalam tentang teori evolusi. Di samping itu, pengajar perlu berwawasan luas agar tidak menganggap religiositas dan penerimaan teori evolusi bertolak belakang. Sementara itu, diskusi ilmiah yang sarat nilai religius dapat menurunkan penolakan teori evolusi.

Penelitian ini menghasilkan informasi bahwa tingkat religiositas tidak selalu menghambat seseorang menerima teori evolusi. Disarankan agar penelitian serupa dapat dilakukan pada populasi lain untuk dibandingkan hasilnya kemudian. Dengan demikian, hubungan negatif antara religiositas dengan penerimaan teori evolusi mungkin terbukti tidak bersifat universal.

Di samping itu, diperlukan penelitian lebih lanjut mengenai hubungan antara aspek psikologis dan sosial lainnya dengan penerimaan teori evolusi. Komparasi penerimaan teori evolusi dapat dilakukan pada mahasiswa di berbagai Universitas dengan ragam kulturnya. Guru Biologi di Jakarta maupun daerah lain dapat dijadikan sampel dalam penelitian semacam ini. 


\section{PUSTAKA ACUAN}

Alters, B. J. \& Nelson, C. E. (2002). Perspective: Teaching evolution in higher education. Evolution, 56(10), 1891-1901. https://doi.org/10.1111/j.0014-3820.2002.tb00115.x

Anderson, L. W., Krathwol, D. R., Airasian, P. W., Cruikshank, K. A., Mayer, R. E., Pintrich, P. R., Raths, J., \& Wittrock, M. C. (2001). A Taxonomy for Learning, Teaching, and Assessing: A Revision of Bloom's Taxonomy of Educational Objectives. New York: Longman.

Allmon, W. D. (2011). Why don't people think evolution is true? Implications for teaching, in and out of the classroom. Evolution: Education and Outreach, 4(4), 648-665. https://doi.org/ $10.1007 / \mathrm{s} 12052-011-0371-0$

Asuero, A. G., Sayago, A., \& Gonzalez, A. G. (2006). The correlation coefficient: An overview. Critical Reviews in Analytical Chemistry, 36: 41-59. https://doi.org/10.1080/ 10408340500526766

Clément, P. (2015). Creationism, science and religion: A survey of teachers' conceptions in 30 countries. Procedia, 167, 279-287. https://doi.org/10.1016/j.sbspro.2014.12.675.

Coleman, J., Stears, M., \& Dempster, E. (2015). Student teachers' understanding and acceptance of evolution and the nature of science. South African Journal of Education, 35(2), 1-9. https://doi.org/10.15700/saje.v35n2a1079.

Dajani, R. (2012). Evolution and Islam's quatum question. Zygon, 47(2), 343-353. https:// doi.org/10.1111/j.1467-9744.2012.01259.x.

El-Menouar, Y. (2014). The five dimensions of Muslim religiosity: Results of an empirical study. Methods Data Analyses, 8(1), 53-78. https://doi.org/10.12758/mda.2014.003

Evans, J. (2017). Turkey bans the teaching of evolution in public schools, diakses 31 Agustus 2018, dari https://learningenglish.voanews.com/a/ turkey-bans-teaching-of-evolution-inpublic-schools/3926756.html.

Evehart, D. \& Hameed, S. (2013). Muslims and evolution: A study of Pakistani physicians in the United States. Evolution: Education and Outreach, 6(2), 1-8, https://doi.org/10.1186/ 1936-6434-6-2.

Futuyma, D. J. (2013). Evolution. Sundeland: Sinauer.

Glaze, A. L. (2018). Teaching and learning science in the 21st century: Challenging critical assumptions in post-secondary science. Education Science, 8(12): 1-8. https://doi.org/ 10.3390/educsci8010012.

Goodwin,L.D. \& Leech,N.L. (2006). Understanding correlation: Factors that affect the size of r. The Journal of Experimental Education, 74(3): 251-266. https://doi.org/10.3200/ JEXE.74.3.249-266.

Hameed, S. (2008). Bracing for Islamic creationism. Science, 322, 1637-1638. https://doi.org/ $10.1126 /$ science.1163672.

Heddy, V. C. \& Nadelson, L. S. (2012). A global perspective of the variables associated with acceptance of evolution. Evolution: Education and Outreach, 5(3), 412-418. https:// doi.org/10.1007/s12052-012-0423-0.

Kwon, O. (2003). Buddhist and Protestant Korean Immigrants: Religious beliefs and socioeconomic aspects of life. New York: LFB Scholarly Publishing. 
Mansour, N. (2010). Science teachers' views of the science and religion vs. the Islamic perspective: Conflicting or compatible? Science Education, https://doi.org/10.1002/ sce. 20418.

Miller, J. D., Scott, E. C., \& Okamoto, S. (2006). Public acceptance of evolution. Science, 313(5788), 765-766. https://doi.org/10.1126/science.1126746.

Moore, R., Cotner, S., \& Bates, A. (2009). The influence of religion and high school biology courses on students' knowledge of evolution when they enter college. The Journal of Effective Teaching, 9(2), 4-12.

Moore, R. \& Cotner, S. (2009). Rejecting Darwin: the occurrence \& impact of creationism in high school biology classrooms. The American Biology Teacher, 71(2), 1-4. https://doi.org/ 10.1662/005.071.0204.

Moore, D. S., Notz, W. I., \& Flinger, M. A. (2013). The Basic Practice of Statistics. (6th Ed.). New York: W. H. Freeman and Company.

Putri, L. O. L., Rahman, T., \& Priyandoko, D. (2017). Analyzing concepts mastery and misconceptions about evolution of biology major students. Journal of Physics: Conference Series, 812(1), 1-6, https://doi.org/10.1088/17426596/812/1/012083.

Rachmatullah, A., Nehm, R.H., Roshayanti, F. \& Ha. (2018). Evolution education in Indonesia: pre-service biology teachers' knowledge, reasoning models, and acceptance of evolution. In Deniz, H. \& Borgerding, L. A. (Ed.). Evolution Education around the Globe. Cham: Springer International Publishing AG.

Ridley, M. (2014). Evolution. (3rd Ed.). Malden: Blackwell Publishing.

Rutledge, M. L. \& Warden, M. (2000). Evolutionary theory, the nature of science \& high school biology teachers: Critical relationships. The American Biology Teacher, 62(1), 123-131. https://doi.org/103.8.12.99.

Sutantoputri, N. W. \& Watt, H. M. G. (2012). Attribution and motivation: A cultural study among Indonesian university students. International Journal of Higher Education, 1(2), 118-129, https://doi.org/10.5430/ijhe.v1n2p118.

Tavares, G. M. \& Bobrowski, V. L. (2018). Integrative assessment of Evolutionary theory acceptance and knowledge levels of Biology undergraduate students from a Brazilian university. International Journal of Science Education, 40(4), 442-458, https://doi.org/ 10.1080/09500693.2018.1429031.

Tekkaya, C., Akyol, G., \& Sungur, S. (2012). Relationships among teachers' knowledge and beliefs regarding the teaching of evolution: A case for Turkey. Evolution: Education and Outreach, 5, 477-493. https://doi.org/10. 1007/s12052-012-0433-y

Trani, R. (2004). I won't teach evolution; it's against my religion and now for the rest of the story. The American Biology Teacher, 66(6), 419-429. https://doi.org/10.1662/00027685(2004)066[0419:IWTIAM]2.0.CO;2.

Wiles, J. R. (2014). Gifted students' perceptions of their acceptance of evolution, changes in acceptance, and factors involved therein. Evolution: Education and Outreach, 7(4): 119. http://doi.org/10.1186/s12052-014-0004-5.

Winkel, W. S. (2014). Psikologi Pengajaran. Yogyakarta: Sketsa. 